\title{
Penerapan Model Problem Based Learning (PBL) disertai Mind Mapping untuk Meningkatkan Hasil Belajar pada Siswa Kelas X SMA Negeri 1 Tawangsari
}

\author{
Bety Wulansari 1*, Nur Rokimah Hanik ${ }^{2}$, Anwari Adi Nugroho ${ }^{3}$ \\ ${ }^{123}$ Program Studi Pendidikan Biologi, Universitas Veteran Bangun Nusantara Sukoharjo \\ *Alamat email koresponden : betywulan07@yaahoo.com
}

\begin{abstract}
Abstrak
Penelitian ini bertujuan untuk meningkatkan Hasil Belajar Biologi Pada Siswa Kelas X IPA 6 SMA Negeri 1 Tawangsari Tahun Pelajaran 2017/2018.Teknik pengumpulan data dalam penelitian ini menggunakan observasi/ pengamatan, tes/ teknik penilaian, dan dokumentasi. Setelah diadakan tindakan kelas, pada siklus I hasil belajar kognitif sebesar 57\%, aspek afektif sebesar $41 \%$ dan aspek psikomotorik 33\%. Dari siklus I ketuntasan belajar dari aspek kognitif, aspek afektif dan aspek psikomotorik belum memenuhi kriteria tuntas, perlu dilanjutkan ke siklus II. Pada siklus II hasil belajar kognitif sebesar $71 \%$, aspek afektif $46 \%$ dan aspek psikomotorik $51 \%$. Pada siklus II telah mengalami peningkatan, tetapi hasil belajar kognitif dan aspek afektif belum mencapai ketuntasan, maka dilanjutkan pada siklus III. Pada siklus III mengalami peningkatan dengan hasil belajar kognitif sebesar $77 \%$, aspek afektif $60 \%$ dan aspek psikomotorik $66 \%$. Sehingga dapat disimpulkan bahwa dengan menggunakan model $P B L$ disertai mind mapping dapat meningkatkan hasil belajar biologi.
\end{abstract}

Kata Kunci: Hasil Belajar Biologi, Mind mapping, Problem Based learning (PBL).

\section{Implementation of Problem Based Learning (PBL) Model Accompanied by Mind Mapping to Improve Biology Learning Outcomes on Student for Class $X$ Students Senior High School 1 Tawangsari}

\author{
Bety Wulansari 1*, Nur Rokimah Hanik ${ }^{2}$, Anwari Adi Nugroho ${ }^{3}$ \\ ${ }^{123}$ Biology Education Department, Universitas Veteran Bangun Nusantara Sukoharjo \\ *Correspondent's email address : betywulan07@yaahoo.com
}

\begin{abstract}
This study aims to improve Biology Learning Outcomes for Grade X Natural Science Students of 6 SMA Negeri 1 Tawangsari Academic Year 2017/2018. Data collection techniques in this study use observation / observation, test / assessment techniques, and documentation. After class actions, in the first cycle cognitive learning outcomes were 57\%, affective aspects $41 \%$ and psychomotor aspects $33 \%$. From cycle I the completeness of learning from cognitive aspects, affective aspects and psychomotor aspects has not met the criteria for completion, it needs to proceed to cycle II. In the second cycle cognitive learning outcomes were $71 \%$, affective aspects $46 \%$ and psychomotor aspects $51 \%$. In the second cycle has increased, but cognitive learning outcomes and affective aspects have not reached completeness, then continued in cycle III. In cycle III experienced an increase with cognitive learning outcomes of $77 \%$, affective aspects $60 \%$ and psychomotor aspects $66 \%$. So, it can be concluded that using the PBL model with mind mapping can improve the Biology Learning Outcomes
\end{abstract}

Keywords: Biological Learning Outcomes, Mind mapping, Problem Based learning (PBL). 


\section{PENDAHULUAN}

Pembelajaran biologi yang ideal haruslah sesuai dengan hakikat keilmuan biologi sebagai sains, yang meliputi obyek dan permasalahan. Disamping itu, pembelajaran biologi hendaknya berpusat pada siswa (student centered) yang menekankan bahwa dalam pembelajaran siswa dapat membangun pengetahuannya. Pembelajaran biologi idealnya memungkinkan siswa melakukan serangkaian ketrampilan proses sains mulai dari mengamati, mengelompokkan (klasifikasi), mengukur, menghitung, meramalkan, mengkomunikasikan, mengajukan pertanyaan (bertanya), menyimpulkan, mengontrol variabel, merumuskan masalah, membuat hipotesis, merancang penyelidikan, melakukan penyelidikan/percobaan.Setelah melakukan serangkaian ketrampilan proses siswa akan mengkonstruk konsep-konsep materi biologi. Selama melakukan serangkaian proses ilmiah, diharapkan dapat dikembangkan sikap ilmiah seperti: jujur, obyektif, teliti, menghargai orang lain, disiplin, dll. Prinsip pembelajaran biologi sangat relevan dengan paham kontruktivistik, dimana belajar merupakan proses pengkontruksian konsep melalui pengalaman oleh siswa, bukan pemberian konsep oleh guru (Sudarisman, 2015).

Penemuan konsep biologi dapat diperoleh siswa melalui pemecahan masalah dengan metode ilmiah. Pembelajaran biologi sebaiknya dilaksanakan dengan pendekatan ilmiah bertujuan untuk menumbuhkan kamampuan berpikir, bekerja, dan bersikap ilmiah serta mengkominikasikannya sebagai aspek penting kecakapan hidup. Oleh karena itu pembelajaran biologi di 48
SMA/MA menekankan pada pemberian pengalaman belajar secara langsung melalui penggunaan dan pengembangan ketrampilan proses dan sikap ilmiah (Ayuliasari, 2017).

Pada kurikulum 2013, guru harus menggunakan pendekatan ilmiah menjadi model dasar dalam pembelajaran dibarengi dengan model Problem Based Learning $(P B L)$. Finkle an Top (1995) dalam Aris Shoimin 2014:130 menjelaskan bahwa Problem Based Learning (PBL) merupakan sistem pembelajaran yang mengembangkan secara stimulan strategi pemecahan masalah, dasar-dasar pengetahuan dan ketrampilan dengan menempatkan siswa untuk aktif dalam pembelajaran.

\section{METODE}

Jenis Penelitian ini adalah Penelitian Tindakan Kelas (PTK). Kegiatan penelitian dilaksanakan pada semester genap pada bulan tahun pelajaran 2017/2018 dimulai minggu ke empat bulan Februari sampai minggu ke satu bulan Mei pada siswa kelas $X$ IPA 6 SMA Negeri 1 Tawangsari, dengan jumlah siswa 35 yaitu 27 perempuan dan 8 laki-laki. Rendahnya hasil belajar siswa dapat dilihat dari nilai ulangan, ternyata dari 35 siswa yang memenuhi KKM hanya 19 siswa (54\%). Dengan Kriteria Ketuntasan Minimal (KKM) yang ditetapkan sekolah pada mata pelajaran Biologi kelas X IPA yaitu 70 . Dengan indikator ketuntasan dari aspek kognitif Jumlah siswa yang memperoleh nilai lebih dari 70 minimal $75 \%$ yaitu 26 dari 35 siswa, aspek afektif yaitu jumlah siswa yang memperoleh nilai diatas 3,5 (skala 4) adalah minimal $50 \%$ yaitu 17 dari 35 siswa dan aspek psikomotorik yaitu 
jumlah siswa yang memperoleh nilai diatas 3,5 (skala 4) adalah minimal 50\% yaitu 17 dari 35 siswa.

Sumber data diperoleh dari dokumen mengenai data siswa dan diperoleh data hasil kognitif dari tes, afektif dan psikomotorik dari observasi. Instrumen penelitian berupa Silabus, RPP (Rencana Pelaksaan Pembelajaran), lembar observasi (aspek afektif dan psikomotorik) dan butir soal tes terdiri dari 10 soal pilihan ganda dan 10 soal uraian. Teknik dan prosedur penggunaan data menggunakan observasi dan tes. Tes menggunakan 4 uji instrumen yaitu tingkat kesukaran butir soal, daya beda butir soal, reliabilitas dan uji validitas.

Penelitian ini terdiri dari 3 siklus, dimana dalam satu siklus tindakan meliputi, perencanaan, pelaksanaan, pengamatan dan refleksi. Berikut adalah skema penelitian tindakan kelas:

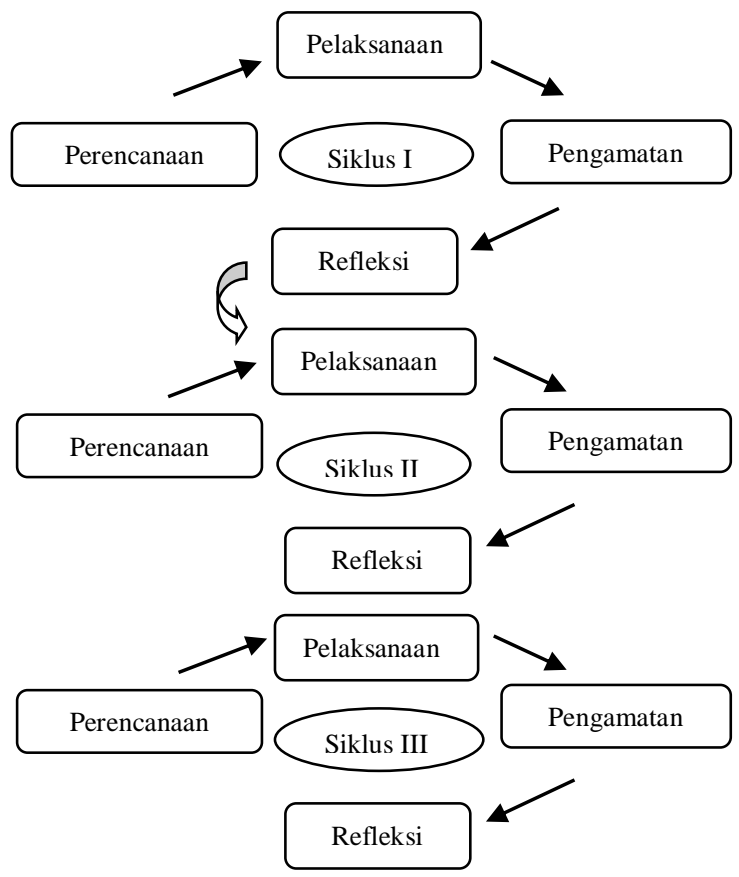

Gambar 1. Skema Pelaksanaan Tindakan Kelas (PTK)

\section{HASIL DAN PEMBAHASAN}

Berdasarkan data hasil penelitian terhadap hasil belajar biologi siswa dari segi kognitif, afektif dan psikomotorik dapat dilihat pada tabel berikut :

Tabel 1. Hasil Belajar Biologi dari Aspek Afektif pada setiap Siklus

\begin{tabular}{lc}
\hline Aspek afektif & Persentase ketuntasan \\
\hline Siklus I & $41 \%$ \\
Siklus II & $54 \%$ \\
Siklus III & $77 \%$ \\
\hline
\end{tabular}

Berdasarkan tabel 1, hasil belajar dari aspek afektif dapat dinilai dari indikator, yaitu: disiplin, jujur, kerjasama dan tanggung jawab. Hasil belajar afektif siklu I sampai siklus III mengalami peningkatan dengan indikator keberhasilan yang ditetapkan dalam penelitian ini minimal 75\%yaitu 26 dari 35 siswa.dalam Problem Based Learning (PBL)membantu siswa dalam mengembangkan ilmunya dengan mencari informasi, pada saat siswa berdiskusi mereka bertanggung jawab terhadap penyelesaian masalah. Sesuai dengan pernyataan, strategi pembelajaran dan model-model pendidikan yang bersifat bebas dan egaliter akan mendukung perkembangan aspek-aspek afektif. Hal ini hanya dapat dicapai lewat proses pendidikan bebas dan metode pembelajaran aksi dialogikal (diskusi, tanya jawab dan debat), keaktifan siswa menjadi unsur yang mata penting dalam menentukan kesuksesan belajar (Asry Budiningsih, 2009).

Tabel 2. Hasil Belajar Biologi dari Aspek Psikomotorik dari setiap Siklus

\begin{tabular}{lc}
\hline \multicolumn{1}{c}{$\begin{array}{c}\text { Aspek } \\
\text { psikomotorik }\end{array}$} & Persentase ketuntasan \\
\hline Siklus I & $34 \%$ \\
Siklus II & $51 \%$ \\
Siklus III & $71 \%$
\end{tabular}


Berdasarkan tabel 2. Hasil belajar dari aspek psikomotorik mengalami peningkatan pada setiap siklus. Hasil belajar dari aspek psikomotorik dapat dinilai dari indikator antara lain terlibat dalam mencari sumber informasi, keterlibatan dalam menemukan gagasan dalam menyelesaikan penyelesaian masalah, kemampuan berkomunikasi dalam presentasi, kemampuan menjawab pertanyaan dalam proses diskusi atau tanya jawab dengan guru dan ketrampilan dalam membuat mind mapping. Dengan indikator keberhasilan yang ditetapkan dalam penelitian ini minimal $75 \%$ yaitu 26 dari 35 siswa. Dalam pembelajaran Problem Based Learning (PBL) dapat mengembangkan ketrampilan dan kreatifitas siswa dalam mengungkapkan gagasan atau pendapat dalam bentuk mind mapping dan siswa dapat mengaplikasikan gagasan atau ide mereka dalam kehidupan nyata. Penggunaan mind mapping dalam model Problem Based Learning (PBL) dapat meningkatkan aspek psikomotorik siswa. Priadi, dkk(2012) mendapatkan bahwa penggunaan model PBL memebrikan kesempatan siswa untuk mengembangkan ketrampilan psikomotoriknya yang berkaitan dengan ketrampilan berkomunikasi, representasi, permodelan dan penalaran. Ini sesuai dengan pernyataan. Mind mapping bisa dibeut peta rute yang digunakan ingatan, membuat kita bisa menyusun fakta dan pikiran sedemikian rupa sehingga cara kerja otak kita secara alami akan dilibatkan sejak awal, sehingga mengingat informasi akan mudah dan bisa diandalkan daripada menggunakan teknik mencatat biasa (Imas dan Berlin, 2015).
Tabel 3. Hasil Belajar Kognitif pada setiap Siklus

\begin{tabular}{lc}
\hline \multicolumn{1}{c}{$\begin{array}{c}\text { Aspek } \\
\text { psikomotorik }\end{array}$} & Persentase ketuntasan \\
\hline Siklus I & $34 \%$ \\
Siklus II & $51 \%$ \\
Siklus III & $71 \%$ \\
\hline
\end{tabular}

Berdasarkan tabel 3, hasil belajar kognitif biologi mengalami peningkatan setiap siklusnya, dengan indikator keberhasilan yang ditetapkan dalam penelitian ini minimal $75 \%$ yaitu 26 dari 35 siswa. Ketika siswa bertanggung jawab dan aktif dalam kegiatan diskusi, menemukan gagasan dan solusi dalam pemecahan masalah, mereka dapat lebih mudah memahami dan mengetahui permasalahan yang mereka pelajari dan ketika dihadapkan dengan tes, mereka dapat mengerjakan soal tes yang benar. Hal ini sesuai dengan pernyataan Wulandari (2013) bahwa model PBL lebih memotivasi untuk menelusuri dan mengeksplorasi pengetahuan sendiri . hal ini juga didukung dengan penelitian yang dilakukan oleh Kharida, dkk (2015) penerapan model berbasis masalah dapat meningkatkan hasil kognitif.

Hasil belajar setiap siklus meliputi aspek afektif, psikomotik dan kognitif mengalami peningkatan dengan menggunalan model Problem Based Learning $(P B L)$ disertai mind mapping. Ini sesuai dengan penelitian Farrand, dkk (2000) yang menyatakan bahwa mind mapping tidak hanya membantu siswa dalam belajar, tetapi mendorong peningkatan dalam level pembelajaran yang lebih dalam terutama dipasangkan dengan model pembelajaran berbasis masalah. Peningkatan hasil belajar biologi siswa, dikarenakan siswa sudah terbiasa 
dalam mengikuti pembelajaran Problem Based Learning (PBL) disertai mind mapping, tanggung jawab anggota kelompok sudah ditunjukkan yang dapat dilihat pada saat berdiskusi, prsentasi, menuangkan ide dan kreatifitas ming mapping memberi tanggapan dan menjawab pertanyaan yang disampaikan tean maupun guru. Hal ini sesuai dengan Mary dan Kitsantas (2013), untuk mempelajari proses dengan mengatur tujuan, mengamati, menggambarkan dan memepertahankan motivasi mereka dari awal sampai akhir pembelajaran, sedangkan guru dapat memberikan semangat, keyakinan, dan strategi untuk membimbing siswa belajar mandiri. Hasil penelitian Nugroho \& Hanik (2015) menyatakan bahwa pembelajaran yang bersifat konstruktifis dan berpusat pada siswa dapat meningkatkan kemampuan kognitif siswa.

Maka dapat dikatakan bahwa penerapan model Problem based learning $(P B L)$ disertai mind mapping dapat meningkatkan hasil belajar biologi siswa. Hal ini sesuai dengan penelitian Fauzi, R (2014) penerapan model problem based learning dapat meningkatka hasil belajar siswa pada kompetensi sikap, pengetahuan dan ketrampilan. Diperkuat dengan penelitian Nurtanto, M., \& Sofyan, H, (2015) bahwa penggunaan model Problem Based Learning (PBL) dapat meningkatkan hasil belajar siswa dari aspek afektif, kognitif dan psikomotorik. Sesuai dengan kelebihan Problem Based Learning (PBL) yaitu menurut Wina Sanjaya (2009) menjelaskan bahwa pemecahan masalah meningkatkan aktivitas siswa, membantu bagaimana mentransfer kemampuan mereka untuk memehami masalah dalam kehidupan yang nyata, mengembangkan pengetahuan barunya dan bertanggung jawab terhadap pembelajaran yang mereka lakukan dan pemecahan masalah dapat mengembangkan kemampuan berfikir kritis dan mengembangkan pengetahuan mereka untuk menyesuaikan dengan pengetahuan yang baru.

\section{KESIMPULAN DAN SARAN \\ Kesimpulan}

Berdasarkan kegiatan penelitian tindakan kelas yang dilakukan di X IPA 6 SMA Negeri 1 Tawangsari Tahun Pelajaran 2017/2018, maka dapat diambil kesimpulan bahwa "Penerapan model Problem Based Learning (PBL) disertai mind mapping dapat meningkatkan hasil belajar biologi siswa dari segi kognitif, afektif (sikap) dan psikomotorik (ketrampilan) pada materi pembelajaran perubahan lingkungan pada kelas X IPA 6 SMA Negeri 1 Tawangsari Tahun Pelajaran 2017/2018".

\section{Saran}

Berdasarkan hasil penelitian dapat disampaikan beberapa saran : 1) bagi siswa dalam pembelajaran Problem Based Learning $(P B L)$ disertai mind mapping, siswa hendaknya dapat meningkatkan kemampuan belajar secara berkelompok, meningkatkan rasa percaya diri dalam menyampaikan pendapat, agar dalam pembelajaran mereka dapat aktif dan kreatif, 2) bagi guru biologi, diharapkan kreatif dan inovatif dalam menggunakan model Problem Based Learning $(P B L)$ disertai mind mapping sesuai dengan materi pelajaran, sehingga tujuan pembelajaran dapat tercapai, 3) bagi sekolah, hasil penelitian menunjukkan bahwa penggunaan model 
Problem Based Learning (PBL) disertai mind mapping dapat meningkatkan hasil belajar siswa, sehingga dapat dijadikan alternatif pembelajaran disekolah, 4) bagi peneliti, penelitian ini dapat digunakan sebagai acuan dalam penelitian selanjutnya dan diharapkan penelitian selanjutnya mampu mengembangkan media inovatif lain sebagai pendukung model Problem Based Learning (PBL).

\section{UCAPAN TERIMAKASIH}

Penelitian ini dapat selesai dengan baik karena bantuan dari berbagai pihak. Oleh karena itu penulis mengucapkan terima kasih kepada kepala sekolah SMA N 1 Tawangsari, jajaran guru biologi yang telah banyak membantu dalam penelitian serta siswa siswi kelas X IPA 6 SMA N 1 Tawangsari Tahun Pelajaran 2017/2018.

\section{DAFTAR PUSTAKA}

Ayuliasari, Citra. (2017). Kesesuaian Rencana Pelaksanaan Pembelajaran (RPP) Kurikulum 2013 dan Implementasinya dalam Mengembangkan Kemampuan Proses Ilmiah di SMA Negeri 3 Yogyakarta. Jurnal Prodi Pendidikan Biologi FMIPA. Universitas Negeri Yogyakarta.

C, Asri Budiningsih. (2009). Mengembangkan nilai-nilai afektif dalam pembelajaran. Journal Yogyakarta: KTP-FIP. Uiversitas Negeri Yogyakarta.

Farrand, P., Hussain F., \& Hennessy E,. (2002). The efficiancy of the "Mind map" Study Technique. Medical educaton. 36;426-431

Fauzi, R., Supriyadi \& Mugiadi. (2014). Peningkatan hasil belajar siswa melalui model
Problem Based Learning. Jurnal Ilmu Pendidikan. Universitas Bandar Lampung.

Imas Kurniasih \& Berlin. (2015). Ragam Pengembangan model pembelajaran. Jakarta: Kata Pena.

Kharida, L.A., Rusilowati, A., \& Pratiknyo, K. (2009). Penerapan Model Pembelajaran Berbasis Masalah Untuk Peningkatan Hasil Belajar Siswa Pada Pokok Bahasan Elastisitas Bahan. Jurnal. Pendidikan Fisika Indonesia. $8(2): 42-47$

Nugroho, A. A., \& Hanik, N. R. (2015). Implementasi Outdoor Learning untuk Meningkatkan Hasil Belajar Kognitif Mahasiswa pada Mata Kuliah Sistematika Tumbuhan Tinggi. Bioedukasi: Jurnal Pendidikan Biologi, 9(1), 41-44.

Nurtanto, M,. \& Sofyan, H,. (2015). Implementasi problem Based Learning untuk meningkatkan hasil belajar kognitif, psikomotorik dan afektif siswa SMK. Jurnal Pendidikan Vokasi. PTK PPS Universitas Negeri Yogyakarta.

Priadi, M.A., Sudarisman \& Suparmin. (2012). Pembelajaran biologi menggunakan model Problem Based Learning melalui metode eksperimen laboratorium dan lapangan ditinjau dari keberagaman kemampuan berfikir analitis dan sikap perduli lingkungan. Jurnal Inkuiri. 1(3):217-226

Sanjaya, Wina. (2009). Strategi Pembelajaran Berorientasi Standar Proses Pendidikan. Jakarta: Kencana Prenada Media Group.

Soimin, Aris. (2014). 68 model pembelajaran inovatif dalam kurikulum 2103. Yogyakarta : Ar ruzz media.

Sudarisman. (2015). Memahami Hakikat dan Karakteristik Pembelajaran Biologi Dalam Upaya Menjawab.

Wina Sanjaya. (2009). Strategi Pembelajaran. Jakarta: Kencana.

Wulandari, B. (2013). pengaruh problem based learning terhadap hasil belajar ditinjau dari motivasi belajar PCK di SMK. Jurnal Pendidikan Vokasi, 3(2):179-191 